\title{
A few Findings in Pecan Propagation ${ }^{1 /}$
}

\author{
Hitoshi IchIKAwA \\ (College of Agriculture, University of Osaka Pref.)
}

\section{Introduction}

The pecan (Carya Pecan ENGL. et GraebN.) was introduced by the late Dr. WALTER, T. SWINGLE in 1915 and its adaptability to the climate and soil of Japan has been proved by the staff of National Horticultural Experiment Station at Okitsu, and elsewhere. ${ }^{15)(20)(22)}$ Time has been wasted, however, to succeed in the wide dissemination of this important nut species mainly by the difficulty of its vegetative propagation. Trials on the practicability of adapting empirical patch budding method(2)(14)(16) (29) showed not entirely failure but is disadvantageous as it requires a large number of stock seedlings, the seed of which must be introduced from abroad as its home supply is very much limited and expensive. The customary method in propargating fruit trees, i. e., veneer crown grafting, is extremely difficult for the pecan as the operation season is too early and too cool to break the dormancy of the stock, despite the scion bud is nearly breaking whenever the budwood is stored in cool places for a considerable period.

The present study was carried on to find out the most practical method by using the simplest and the most acquainted method to average propagators and minimizing the expenditure to raise a year-old plant of known variety to answer the increasing demand for home planting. It is generally believed that the hardwood stem cuttings or layers will not take root to an appreciable extent or otherwise a complete failure, ${ }^{(4)(5)(10)}$ whereas the softwood

1) Inaugural dissertation for the fulfilment of master degree requirement, Prof. Tyôzaburô TANAKA, praeses. The respondent is a graduate of the University of Chiba, 1955, Batchelor in Agricultural Science, graduating the course of Multipurpose Agriculture.

Contribution No. 7, Tanaka Institute of Citriculture, and Horticultural Science, Department of Horticulture, College of Agriculture, the University of Osaka Prefecture.

Numbers in parenthesis in the text refer to the quotations in Literature Cited.

Recieved for publication January 14, 1958 cuttings can be rooted under continuous mist ${ }^{(8)}$. The use of root-inducing chemicals by inlaying treated tooth-pick at the cut end was experimentally shown a success ${ }^{(18)}$, but its universal use in common practice in this country seems rather skeptical. GOSSARD ${ }^{(7)}$ obtained own-rooted cuttings by etiolated trench layering and by marcot in conjunction with the tooth-pick method, but such practice does not seem practical under Japanese conditions. Although EAMES and MACDANIELS ${ }^{(5)}$ described that the root cuttings of Carya is difficult, our experience with the pecan show just opposite and is easy ${ }^{(2)}$, in agreement with the statement of ADRIANCE and BRISON ${ }^{(1)}$. To the advantage for us, root materials are readily accessible in any quantity where seedling plants exist. Of course, no orchard plant true to type is expectable by using such cuttings, and they have been in practical use for stock plant like the crab apple and Lotus persimmon. (6)(19)

It is possible, therefor, that root cuttings can be used as the stock for known variety of the pecan, when any convenient method be developed in graftage. Unpublished data of Mr. T. HORI on this process appeared to be promising after one year's trial on a small scale at Sakata, Konkô-chô, Okayama Prefecture. The successful union in such a graftage is undoubtedly dependent on the environmental condition which ensures the quick development of callus tissue on the contacting surface of the scion and stock. This is true with the stem cuttings and its failure might be simply the lack of proper external condition to form callus tissues.

Although the use of properly equipped hot-bed is not practiced in the United States ${ }^{(13)}$, acceleration of root growth of the stock plant by accomodating bottom-heated propagation frame is a common practice in England for walnut( ${ }^{(9)}$, and KôMA(12) proved it in Japan. Generally, no callus formation is observed in either cool-bed cuttings or outdoor grafting even in May when the air temperature is around $17^{\circ} \mathrm{C}$. Preliminary tests at the University ground in 1956 proved that the hardwood stem cuttings of the pecan takes root when air temperature arises above $24^{\circ} \mathrm{C}$ in a greenhouse electrically heated, 
whenever the cut-sticks are either treated or untreated with $10 \%$ glucose solution. All roots are observed to have been developed from the callus as illustrated in Fig. 1 and 2, and no lateral root from

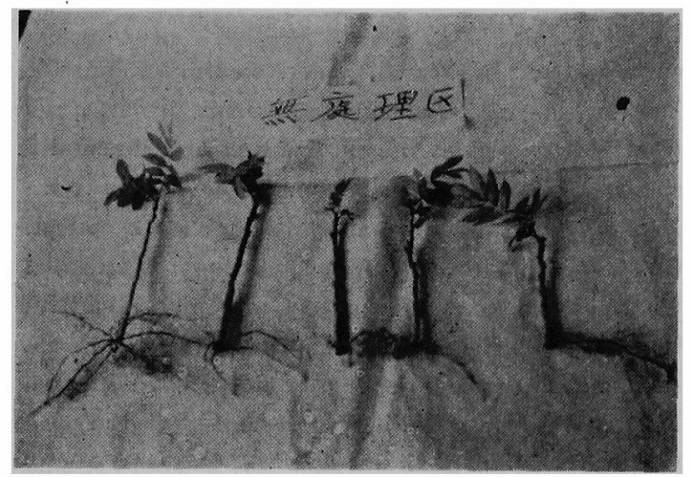

Fig. 1. Hardwood cuttings rooted in green house without treatment (49 th day after being operated)

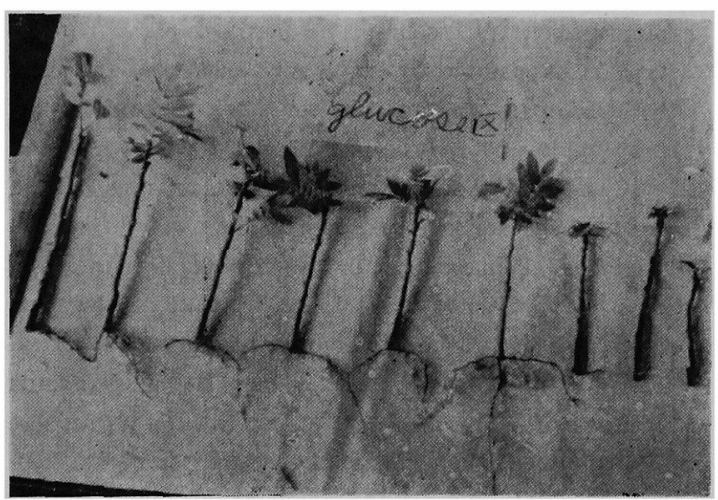

Fig. 2. The same, treated with $10 \%$ glucose solution before the operation (taken out of bed on the same day)

the side of the stick is seen at any occasion, suggesting that the callus formation is essential to develop the root from the cuttings. Likewise, the callusing of graft union must require a little higher degree above the seasonal air temperature, and such condition can easily be attained by using heated bed instead of using a glass house, inaccessible for average nurserymen.

From the richness of the propagation material, a large scale trial is scheduled at Mr. HORI's farm in 1957 , by an installation of a $9 \times 1.8 \mathrm{~m}$ propagation frame (16. 2 sq. $m$ in area) electrically bottom-heated, in addition to two same sized frame accomodated with straw manure as heat source. The experiment commenced on April 24, but a number of year-old dormant budwoods representing 9 standard varieties and selections had been collected several months ahead (from Jan. 12 to 18) and stored in a cool cellar keeping at a temperature of about $10^{\circ} \mathrm{C}$. A large number of tap roots were cut during a long course between January to March (some a few days ahead) from seedling pecan trees of three to eight years old, for the use as the rootstock, most of them being stored buries under the ground. The procedure and the result of experiments are described in the following chapters.

\section{“Grafted Root-Cutting ",}

Tap roots of 0.6 to $1.2 \mathrm{~cm}$ in diameter were cut in to short pieces of about 8 to $12 \mathrm{~cm}$ long (rarely up to $20 \mathrm{~cm}$ ), the upper end being smoothly cut in plain at right angles to the side. One end of the cut surface is splitted by a straight-bladed knife at the perifery, tangentially to the cambium layer, and the bark is pulled down by fingers which would release easily to a desired length to fit the scion, the bark being kept unremoved to overlap the back of the scion afterwards. Just before this operation, dormant scion with several primary buds on (rarely single-budded) was cut from the budwood, the distal end of which is sharply wedged at any convenient side. The other side of the scion just opposite to the wedge, is carefully shaved off about $2 \sim 6 \mathrm{~cm}$ long (mostly $3 \sim 4 \mathrm{~cm}$ ) with a sharp knife blade along or a little beyond the cambial layer, making the cut surface smooth enough and wide enough to fit the slipped surface of the stock wood. In inserting the scion between the bark and wood of the stock root, the cut surface of the former should be placed as deep as possible, keeping the wedge outside and covering the strip of bark left uncut, holding the setting secure by the aid of fingers. The union portion is quickly wrapped by a piece of vinyl cloth large enough to cover the upper part of the scion exposed above the top of the stock root. No waxing is needed as recommended by MORRIS(14). The vinyl covered graft portion is securely fastened together by a piece of beaten rice straw, which is commonly used in place of the raffia fiber. The whole piece is then placed slantingly on the hot-bed medium and buried as deep as the upper half of the grafted scion is disclosed above the ground level. The distance between each 
grafted cutting will be about $14 \mathrm{~cm}$ apart from each other, and the frame is kept open during day time, except shadowing is needed to prevent direct sunshine or rain.

Within two weeks or so, the bud which did not take starts to deteriolate, while buds taken commence to grow vigorously but a few remains green without any sign of collapse. Individuals with living buds, including those not started, must be transplanted without waiting the rooting of the stock.

They are removed from the bed and planted to the nursery row outdoors. The soil of the nursery must be fertile, well tilled, and contain sufficient amount of moisture. There are two good chances for transplanting, one about ten days after the sprouting of buds, and the other at their elongation into $15 \sim 20 \mathrm{~cm}$ of new growth. Moving the cuttings out of bed will begin on 25 th day from the start and will last until about 40 th day. Cuttings with sprouted buds only about one to two $\mathrm{cm}$ long are easily transplanted while those with expanded leaves find some difficulty for certain variety like Stuart. In moving the latter, a few leaves must be picked off and the nursery should be properly shaded to prevent too much of transpiration. At any rate, the transplanting should end before the middle of May from the safety point of view.

The individual with buds which did not start while in bed, will open after transplanting, developing into satisfactory nursery plant. A few of such plants will fail perhaps from the lack of vigor of the original budwood, bud their percentage will be very low. Of 2300 individual cuttings grafted, operated by the author himself, more than $1530 \mathrm{in}$ dividuals were suitable for such transplanting, about $80 \%$ of which will develop into salable plants in the same fall.* The takage, of course, depends much upon the skill of the operator, and higher percentage can be expected if somebody else with skilled hand had been substituted. Nine varieties and selections** at the disposal for this experiment showed almost $s^{\text {imilar result, and Money Maker will present an }}$

* The loss is mostly due to the defoliation, being attacked by leaf-eating insect, Prionus insularis MOTSCHULSKY.

** Standard varieties used are Stuart, Success, Nellis, Money Maker, Schley and Curtis, while selections, named by Mr. HoRI, i. e., Kuwano Wase, San'wa Wase, and Ninomiya No. 2, were also used. example of the average result for the present method as follows:

\begin{tabular}{c|c|c|c|c}
\hline $\begin{array}{c}\text { No. of } \\
\text { individual } \\
\text { cuttings } \\
\text { grafted }\end{array}$ & $\begin{array}{c}\text { No. of } \\
\text { plant } \\
\text { distinctly } \\
\text { failed }\end{array}$ & $\begin{array}{c}\text { No. of } \\
\text { plant } \\
\text { started } \\
\text { sprouting } \\
\text { in the bed }\end{array}$ & $\begin{array}{c}\text { No. of } \\
\text { plant } \\
\text { with } \\
\text { dormant } \\
\text { buds }\end{array}$ & $\begin{array}{c}\text { Ultimate } \\
\text { No. of } \\
\text { plants } \\
\text { obtained } \\
\text { after trans- } \\
\text { planting }\end{array}$ \\
\hline $\begin{array}{c}187 \\
(100 \%)\end{array}$ & $\begin{array}{c}22 \\
(11.8 \%)\end{array}$ & $\begin{array}{c}155 \\
(82.9 \%)\end{array}$ & $\begin{array}{c}10 \\
(5.3 \%)\end{array}$ & $\begin{array}{c}163 \\
(87.1 \%)\end{array}$ \\
\hline
\end{tabular}

A detailed study was made with ten individuals of each variety in order to roughly estimate the desirable size of the scion, the length of the stock root and that of the shaved surface, the angle of terminal wedge, etc. So far as it was confirmed, the scion wood should be fully matured, long enough and thick enough ( $12 \mathrm{~cm}$ better than $8 \mathrm{~cm}$ in length, and $1.2 \mathrm{~cm}$ over $0.9 \mathrm{~cm}$ in thickness), and to be wedged in rather broad angle, say about $40^{\circ}\left(35^{\circ} \sim\right.$ $45^{\circ}$ ). After all, the wedged surface should be as smooth as possible, since this part heals earlier than shaved surface contacting the wood of the stock. The shaved portion of the scion is to be comparatively long so as to fit the stock wood sufficiently deep. The thickness of the shaved-off bark portion would bo $0.5 \sim 1 \mathrm{~mm}$ and the cambium, not the phloem, must be remaining as far as possible on the wood. The stock root of preferably long piece gave better result than shorter ones, and those bearing larger numbers of side roots were more successful. Upper piece of root near the crown seems to be better avoided, or otherwise use it after removing the stem part.

Discussion: The terminology of this kind of proagation method would be worth while to be considered. The method seems not uncommon in apple as it is illustrated by KAINS and MCQUESTEN(11), in figs. $227,229 \mathrm{x}$ and 230 , in which whip graft is practiced. The term "root grafting", together with "whole-root graft" and "piece-root graft" are used by these authors, but this term does not indicate that it is essentially a modification of root cutting. R. J. GARNER seems to have placed it under the category of "grafting-cutting "***, but even the reverse "cutting-grafting" may not show the exact status of the method and is rather confounding.

*** Curtesy of Prof. J. AOKI of Hirosaki University in calling attention of the literature: GARNER, R. J., in Technical Communication No. 14, Imp. Bur. Hort. \& Plantation Crops, 1944. 
The most adequate term seems to be "grafted rootcutting" without regards what kind of grafting model be adopted. By the lack of literature at hand, it was not confirmed whether this term has been used in anywhere else or not.

The most appropriate season for the operation will be throughout April and May, when the temperature of outside cool-bed will be far below to reach $20^{\circ} \mathrm{C}$. This degree, however, will be easily reached by the hot-bed in which the grafted portion is warmed up by heat generated by stool manure imbedded. Electrically heated bed is more desirable as temperature control is much easier, keeping it nearly constant between $20^{\circ} \mathrm{C}$ and $25^{\circ} \mathrm{C}$, at which callus formation of the graft union will take place satisfactorily. Still higher temperature is not harmful and the callus formation will be greatly accelerated ${ }^{3)}$, if heat economy is not taken into consideration. The cost of installation of such hot frames is not expensive, as such grafted root sticks will take little room, and 50 cuttings or more can be raised per square meter of the bed surface. Heating also can be managed economically if the minimum requirement is to be fulfilled to maintain the set efficiently.

\section{Callus Formation in Cuttings raised in Hot-bed}

By using electrically heated hot-bed, hardwood stem cuttings are raised under controlled temperature of $20^{\circ} \mathrm{C}$, or a little over, never coming down below. Callus formation on the cut surface became visible as early as 17 days after being stuck on the hotbed. Watering was being controlled to a degree just moistening the medium (coarse sand). Rooting took place after 40 days under such a condition. No callusing took place on stem cuttings outdoors. In both cases, wooden frame of the size $65 \times 30 \times 35 \mathrm{~cm}$ are buried into ground, filled with coarse sand* to which the sticks are placed slantingly, one half of the whole length being hidden under the ground level. All cuttings of either lot are handled just alike, but one being successfully rooted and the other failed. The only difference in these cuttings to start callusing seems to be the contrasting temperature, i. e., $20^{\circ} \mathrm{C}$ or a little over, versus $17^{\circ} \mathrm{C}$ or below, It will not be necessary to keep bed temperature constantly above $20^{\circ} \mathrm{C}$ for callus formation; only

* Fine sand is preferable, but it was not obtainable at Sakata, where the experiment was carried on. one or two days of above $20^{\circ} \mathrm{C}$ will eventually compell the cambium to break the rest and the callus tissue will develop accordingly.

Microscopically observing, cambial activity is noticed within 10 days on the transverse section of the cutting sticks, which is quite evident if the microphotograph taken on 10th day is compaired with the initial figure in its resting period (Fig. 3 and 4). On the 17 th day, a complete ring of callus tissue is seen at the place of the initial cambial layer, and the breakage of bark tissue at one (or two or more) place (or places) are observed by the eruption of the greatly expanded callus cell masses (Fig. 5). Through such radial expansion of callus tissues, the cut surface of the stick becomes completely covered by soft callus masses, as illustrated in Fig. 6 and 7 . This stage is reached at about 20 th day from the initial setting. On 26 th day, the root tissue is differentiating at the core of radial callus masses and the adjacent area, as shown by the deep shade on low magnification micro-photograph (Fig. 8). These series of pictures are good enough to illustrate that no root primordia exist in woody tissues of pecan shoot, and the callus developed from the cambial layer is the cell organization from which the root tissue is to be differentiated. Temperature above $20^{\circ} \mathrm{C}$ seems to be essential to the succeeding

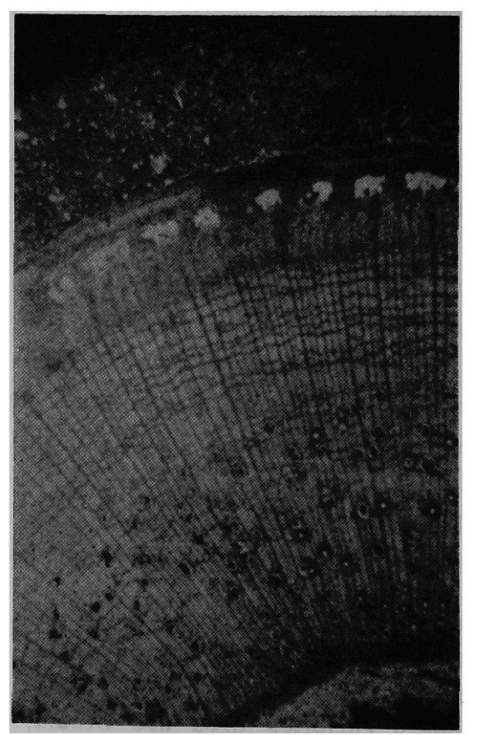

Fig. 3. Transverse section of pecan shoot before placing in hot-bed, showing dormant cambium tissue. (Stained by borax carmine). Approximately $\times 30$. 


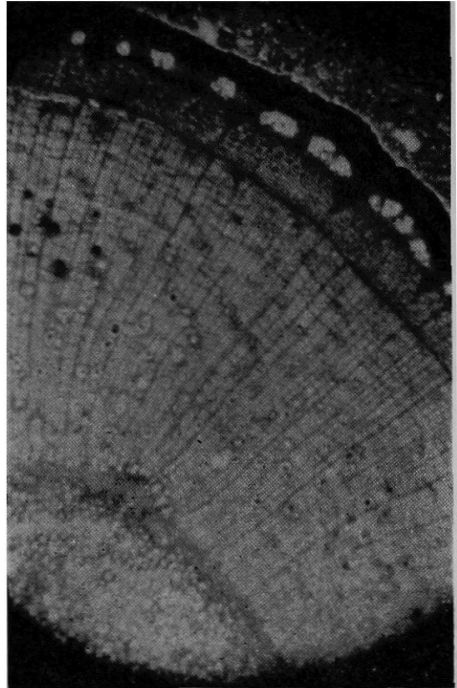

Fig. 4. Piece of cutting shoot near the cut surface after being placed in the hot-bed for 10 days, showing cambial activity already commenced.

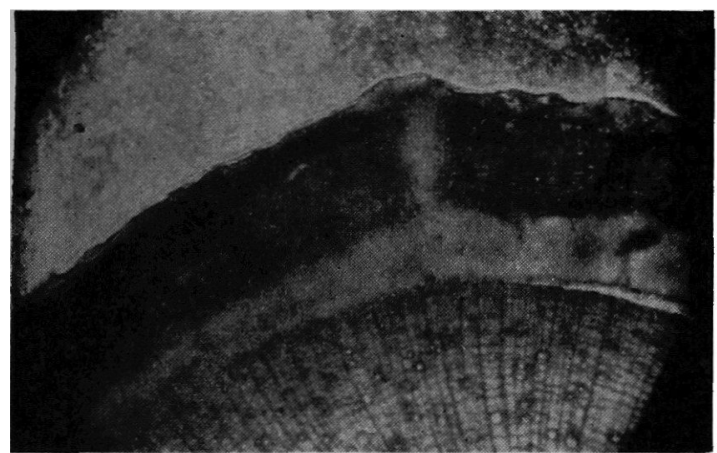

Fig. 5. A section of similar cutting shoot after 17 days in hot-bed, indicating callus ring and its radial projection breaking the bark tissue at one place.

stages of development to initiate the root from the callus cell masses.

Discussion: The process of root initiation from the callus masses is not well demonstrated in Carya as the material is very hard to get access. Presumably, callus cambium must be differentiated at first and then the vascular tissues would follow to develop, judged from the illustration of ESAU's Plant Anatomy (New York, John Wiley, 1953) pl. 57 on p. 675. In Fig. 8, of the present author, the position of vascular tissues developed from cambial zone of callus is shown by darker shaded zone lying a little

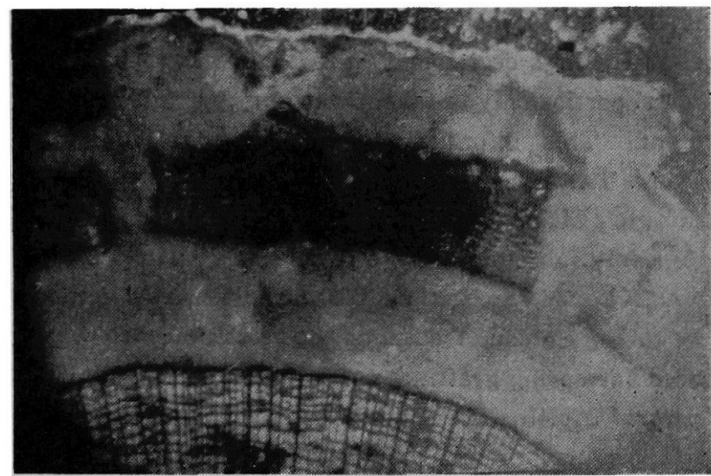

Fig. 6. A section of cutting shoot near the bottom after 20 days from the beginning, showing well formed callus ring, its radial projection, and extracortical covering of callus masses. No root tissue observed.

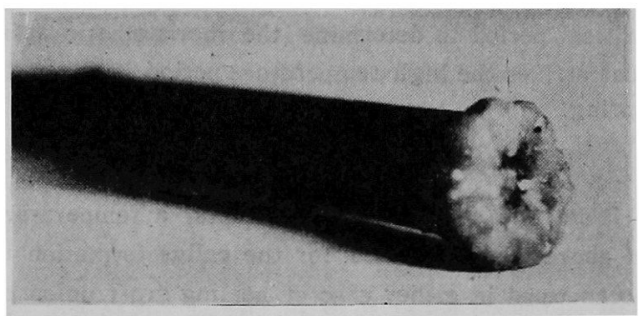

Fig. 7. Macroscopical view of the bottom of the same ( 17 days after being stuck), showing well formed callus tissue on the cut end.

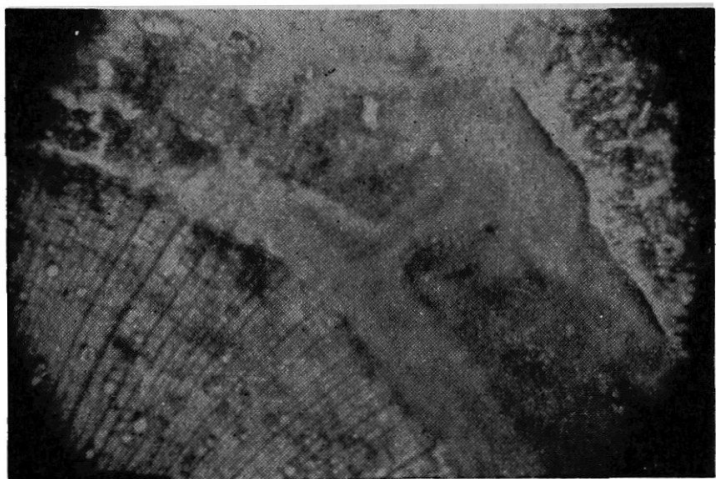

Fig. 8. A section of cutting shoot (magnified) after 26 days, showing dark shade in callus tissues as the result of the differentiation of vascular tissue of the root.

beyond the midline of callus ring. This roughly corresponds to the position of vascular tissues formed from cambium in callus, illustrated by ESAU.

According to verbal information from $\mathrm{Mr}$. M. 
KURAHASHI, a well trained propagator of the pecan, stem cuttings occasionally take root when the terminal portion only is taken from very young seedling plant. This information is quoted on p. 261 of Prof. TANAKA's Lecture Series in general horticulture (Chapter 8, nut fruits: Published by Tokyo Agricultural University Press, 1953). Mr. KURAHASHI's experience must have based upon the practice by saving the top of seedling root stock when it was used for spring grafting, which takes place in early part of April. It is quite possible that the day temperature of his place, south-eastern part of Shikoku Island, may rise above $20^{\circ} \mathrm{C}$ before the 10 th of April, as even in the University field at Sakai, temperature readings of April 6, 7, 8, 9 and 10 reached to $19.4,20.2,21.8,22.4$ and 19.9 , respectively in 1956. Such a temperature will undoubtedly cause the cambium to start its activity when the critical period to determine the meristematic start just strikes the high temperature period in the early spring.

\section{General Discussion and Summary}

From the foregoing experiments, a temperature of above $20^{\circ} \mathrm{C}$ is needed for the callus formation in pecan wood in either case of healing graft union or rooting dormant stem cuttings. The failure of hardwood cuttings at Sakata in outdoors must be due to the inadequacy of the cutting bed and low temperature which did not reach to the required degree. The best condition to safeguard the normal cambial activity can be reached easily by preparing a hotbed heated either by electricity or by stool manure. Fig. 9 shows the union of the scion and stock root after the callus is well formed. The vinyl cover must have contributed to keep the moisture inside, satisfactorily, which is not show in the picture. Oxidation by exposing the cut surface of both scion and the stock root is thus prevented, ultimately causing the bud to start sprouting (Fig.10).

The application of detached root pieces in place of seedling stocks for propagating pecans is quite satisfactory from the viewpoint of the readiness of union between the cut surfaces of both scion and root, whenever the simplest method such as veneer grafting is practiced. The operation is quick enough to work a large number of plants indoors and a considerable number of grafted sticks can be placed in the hot-bed without consuming much space. Where the supply of seedling root is plentiful, this

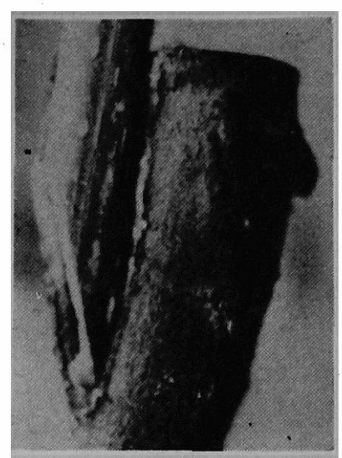

Fig. 9. Side view of the graft union between. pecan scion and its own root in veneer grafting, showing ideal callus formation on both shaved and wedged surfaces (vinyl cover wrapping the graft being removed before photographing)

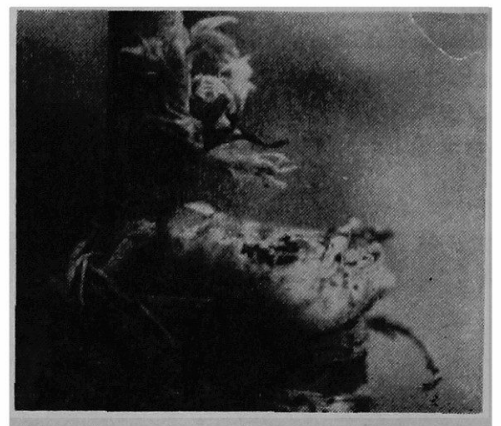

Fig. 10. Sprouting of scion bud after being " taken "

method saves two or three years for the prepara tion of rootstock through raising seedling individu als. Hence it is most economical to obtain a graft ed plant with very little requirement of time and labor. At the same time, it can be expected to produce its own root as the number of initial stock root is limited at the time of operation. This is the case with the early varieties of apple, and the pecan will not be the exception. ROMBERG(17) developed a complicated method to obtain own-rooted pecans, but this simple method herein described will undoubtedly take its place in practical use. The root tissue development within callus tissue may be an uncommon case(1), but is fortunate that the pecan has this feature and is greatly advantageous to propagators as the callusing can be forced in such a simple way as the experiment indicates.

The result of the author's trials is summarized as follows :

1. Pecan can be propagated very easily by grafted root cutting method through the use of perennial 
root piece and dormant scion, worked together in simple veneer grafting method. The wounded surface is completely enveloped by a piece of vinyl cloth before tying together, and the whole stick is placed deep enough on heated bed keeping temperature a little higher or at least at $20^{\circ} \mathrm{C}$.

2. Hardwood stem cuttings can be rooted easily by using the hot-bed prepared in the similar manner.

3. In both cases, visible callusing takes place within 17 days under heated condition, and in the case of stem cutting cambial activity takes place within 10 days, and root tissue differentiation occurs at least after 26 days at the core of callus masses. The projection of cutting root will follow within a few weeks, taking about 40 days from the beginning.

4. No root primordia are present in the wood of pecan shoot, and the entire cambial layer near the cut surface converts into callus tissue within 17 days when the desired temperature is applied.

The author wishes to express his warmest thanks to Prof. T. TANAKa in conducting the present experiment and preparing the manuscript. His appreciation is due to $\mathrm{Mr}$. $\mathrm{T}$. HORI in preparing materials and giving valuable advices throughout the course of experiment at his place. He is also grateful to Mr. H. YoshimuRA in rendering assistance in field works at the University.

\section{Literature Cited}

(1) Adriance, G. W. \& BRIson, F. D.: Propagation of horticultural plants. New York \& London, McGraw-Hill, 1939.

(2) BaIley, J. E. \& Woonroof, J. G. : Propagation of pecan. Georgia Agr. Exp. Sta., Bull. 112, (22 pp.) 1902.

(3) BRISON, J.A.: The storage and seasoning of pecan budwood. Texas Agr. Exp. Sta., Bull. 478, (26 pp.) 1933.

(4) Chandler, W. H.: Deciduous orchards. Philadelphia, Lea \& Febiger, 1951.

(5) EAMES, A. J. \& MacDanIELS, L. H. : An introduction to plant anatomy. ed. 2. New York \& London, McGraw-Hill, 1947.

(6) FUJII, T.: Some problems on propagation in fruit trees (Japanese). New Principles for Horticultural Technique, $1: 186 \sim 187$, Tokyo, Yokendo, 1955.

(7) GoSSARD, A. C.: Rooting pecan stem tissue by layering. Proc. Amer. Soc. Hort. Sci. 38 :
$213 \sim 214,1941$.

(8) - The rooting of pecan softwood cutting under continuous mist. ibid. 44 : $251 \sim 254,1944$.

(9) Howes, F. N.: Nuts, their production and everyday use. ed. 2. London, Faber \& Faber, 1953.

(10) IMPERIal BUREAU of Fruit Production : Vegetative propagation of tropical and subtropical fruits. Imp. Bur. Fr. Prod., Tech. Comm. $7: 37 \sim 40$ (Hicoria Pecan), 1936.

(11) KaIns, M. G. \& MCQuesten, L. M.: Propagation of plants. new ed. New York, Orange Judd, 1956.

(12) KомA, S.: A practicable study in walnut grafting propagation (Japanese). Agr. \& Hort. 26 (11) 1201 1202, 1952.

(13) Mahlstede, J. P. \& Haber, E. S.: Plant propagation. London, Chapman \& Hall, 1957.

(14) MorRis, R. T.: Nut growing. New York, Macmillan, 1931.

(15) ÔsAWA, N.: The culture of pecans (Japanese) Agr. \& Hort. 27 (8) 889 891, 1952.

(16) REED, C. A. : Nut-tree propagation. U. S. Dept. Agr., Farmers' Bull. 1501, (46 pp.) 1926.

(17) ROMBERG, L. D. : Use of nurse seedlings in propagating the pecan from stem cuttings. Proc. Amer. Soc. Hort. Sci. 40:298 300, 1942.

(18) SMiTh, C. L. \& RomberG, L. D.: A method for treatment of cutting and roots of the pecan with root-inducing chemicals. Pl. Physiol. 14 : $177 \sim 1781939$.

(19) Stoutmeyer, V. T. et al.: Some observations. on the production of own-rooted apple stocks from root cuttings. Proc. Amer. Soc. Hort. Sci. $32: 343 \sim 346,1936$.

(20) TANaka, T. \& Kurahashi, M.: The culture of the pecan (Japanese). Tokyo, Shin'yaku Shobô, 1952.

(21) TANakA, Y.: Studies in the cuttings of fruit trees and their root stock plants (Japanese).

Agr. \&. Hort. 7 (2) 241 256, 1932.

(22) TANikAWA, R.: The pecan and its culture (Japanese). Hort. Stud. (Okitsu) 24:20 28, 1929.

(23) TAyloR, Wm. A.: Pecan, BaIley, L. H., Stand. Cyclop. Hort., New York, Macmillan, 1916. (pp. 2517 2523). 